\title{
Имидж ведомств сектора безопасности как инструмент стратегической коммуникации
}

\section{Ирина Лисичкина}

Национальная академия, Национальная гвардия Украины, Харьков, Украина

Резюме: В этой статье освещается проблема имиджа в качестве инструмента стратегической коммуникации для ведомств сектора безопасности. Развитие имиджа какого-либо ведомства сектора безопасности обрисовано с учетом формирования имиджа и его последующего улучшения. Формирование имиджа основывается на принципах объективности, открытости, достоверности и доверия, и в то же время для избегания введения в заблуждение и манипуляций. Перечислены лучшие практики и провалы при формировании имиджа ведомств безопасности на примере опыта США и Украины. Предложенные указания по формированию имиджа ведомств сектора безопасности охватывают рекомендации автора по созданию эффективного дискурса и соответствующее развитие институциональной политики по этому вопросу.

Ключевые слова: дискурс, формирование имиджа, улучшение имиджа, ведомство сектора безопасности, стратегическая коммуникация, стратегия.

\section{Введение}

Гибридный характер современной войны является существенным сдвигом, характеризующимся тем, что стратегии использования силы становятся дополнением к информационным и коммуникационным стратегиям. ${ }^{1}$ Имея

1 Anaïs Reding, Kristin Weed, and Jeremy J. Ghez, NATO's Strategic Communications Concept and its Relevance for France, Prepared for the Joint Forces Centre for Concept 
ввиду одновременное с этим развитие средств ведения войны и средств коммуникации, можно полагать, что «сообщество стратегической коммуникации может многое почерпнуть из работ Клаузевица и из современных попыток военной теории понять, что в данное время происходит в сфере стратегической коммуникации». ${ }^{2}$

Имидж ведомств сектора безопасности является могущественным инструментом гибридных войн в сфере информации и коммуникации. В рамках сценария глобальной войны, имидж считается оружием для выстреливания дискурса ведомства с желаемой точностью, желаемым темпом и в желаемом объеме. Имидж ведомств сектора безопасности эффективно используется для таргетирования умонастроений публики и образа ее мышления, как во время войны, так и в мирное время.

В этой статье рассматривается проблема определения рамок корпоративного имиджа в качестве инструмента стратегической коммуникации для ведомств сектора безопасности и описываются лучшие практики формирования имиджа ведомств сектора безопасности. Из всего многообразия подходов к стратегической коммуникации в целом, в статье рассматриваются только те коммуникационные аспекты имиджа, которые оказывают влияние на способности ведомств сектора безопасности.

Исследование, лежащее в основе данной статьи, является мультидисциплинарным и находится на пересечении нескольких социальных и гуманитарных наук: философии, имиджелогии, коммуникативной лингвистики, когнитивной науки, медиа лингвистики, исследований дискурсов и социолингвистики. Этот синергетический характер порождает необходимость обращаться к разным типам источников для всеохватного обзора литературы по данному вопросу, для описания лучших практик в формировании имиджа вооруженных сил и правоохранительных органов и для конструирования рамок имиджа в процессе стратегической коммуникации, осуществляемой ведомствами сектора безопасности.

\section{Стратегическая коммуникация в секторе безопасности}

\section{Сущность стратегической коммуникации}

Стратегическая коммуникация приобрела особую популярность в сферах бизнеса, политики и в военной области во второй декаде двадцать первого века и, как относительно новое понятие, она все еще порождает споры об ее сущности, охвате и функциях.

Development, Doctrine and Experimentation, France (Santa Monica, CA: RAND Corporation, 2010), 4.

2 Simon M. Torp, "The Strategic Turn in Communication Science: On the History and Role of Strategy in Communication Science from Ancient Greece," in The Routledge Handbook of Strategic Communication, ed. Derina Holtzhausen and Ansgar Zerfass, (New York, London: Routledge, Taylor and Francis Group, 2015), 24. 
Для целей этого исследования было выбрано определение Хольцхаузена и Зерфасса, потому что в нем подчеркивается общественная сфера: «Стратегическая коммуникация есть практика преднамеренной и целенаправленной коммуникации, которую агент коммуникации осуществляет в публичной сфере от имени субъекта коммуникации для достижения поставленных целей». ${ }^{3}$

Концепция стратегической коммуникации НАТО предназначена для гарантирования того, что аудитории будут получать ясную, честную и своевременную информацию, касающуюся действий Альянса и того, что интерпретация посланий Альянса не будет предоставлена единственно противникам НАТО или другим аудиториям. ${ }^{4}$

Надо отметить, что в сентябре 2009 года НАТО разработало свою Политику по стратегической коммуникации в ответ на требования «современной информационной среды», которая «напрямую оказывает влияние на то, как действия НАТО воспринимаются ключевыми аудиториями», благодаря тому факту, что «восприятие всегда имеет отношение и оказывает прямое воздействие на успех операций и политик НАТО». ${ }^{5}$ Таким образом, впечатления аудитории, касающиеся НАТО, иными словами, его имидж были основной заботой при разработке этой политики. Эта точка зрения совпадает с концепцией бизнеса о стратегической коммуникации, поскольку «целью стратегической коммуникации является поддержание здоровой репутации субъекта коммуникации в общественной сфере». ${ }^{6}$

В этом отношении существенно подчеркнуть, что стратегическая коммуникация занимается в основном стратегиями влияния в плане восприятия организации в качестве результата, а не просто СМИ, и информацией в качестве каналов и содержания, когда «одна или сочетание нескольких переменных (т.е. источник посланий, сами послания, канал для передачи посланий и реципиент посланий) может привести к когнитивным и поведенческим изменениям».7

Стратегическая коммуникация жизненно важна сегодня для любого ведомства сектора безопасности в любой стране. Стратком отделы и/или другие структуры, ответственные за стратегическую коммуникацию, были созданы практически в каждом ведомстве. В 2013 году НАТО создало свой Центр передового опыта в области стратегической коммуникации в Риге, Латвия. Журнал «Стратегические коммуникации в обороне» ориентирован

3 Derina Holtzhausen and Ansgar Zerfass, "Strategic Communication: Opportunities and Challenges of the Research Area," в The Routledge Handbook of Strategic Communication, 74.

4 РО(2009)0141, цитировано по Reding and Weed, "NATO's Strategic Communications," 4.

5 NATO Policy on Strategic Communications, SG(2009)0794, 1.

6 Holtzhausen and Zerfass, "Strategic Communication," 5.

7 Kenneth E. Kim, "Framing as a Strategic Persuasive Message Tactic," в The Routledge Handbook of Strategic Communication, 285. 
на сведение воедино военных, академических, деловых и государственноадминистративных знаний в этой сфере. В нашем информационном веке для ведомств сектора безопасности стало нормой поддерживать свои собственные вебсайты, иметь свои собственные СМИ и собственные профили в социальных сетях.

Осознавая нехватку доктринальных руководящих указаний, Объединенное командование вооруженных сил США создало, а затем актуализовало свое, предшествующее доктринальным документам, «Руководство для командиров по вопросам стратегической коммуникации и коммуникационной стратегии» для того, чтобы помочь «командирам объединенных сил и их штабам понять альтернативные точки зрения, технологии, процедуры, 'лучшие практики' и организационные возможности». 8 Это Руководство для командиров содержит комплексный анализ военных способностей, связанных с информацией и коммуникацией (Фигура 1).

Есть несколько основных принципов стратегической коммуникации, которые должны знать субъекты, осуществляющие коммуникацию:

- Создание здоровых профессиональных отношений с СМИ

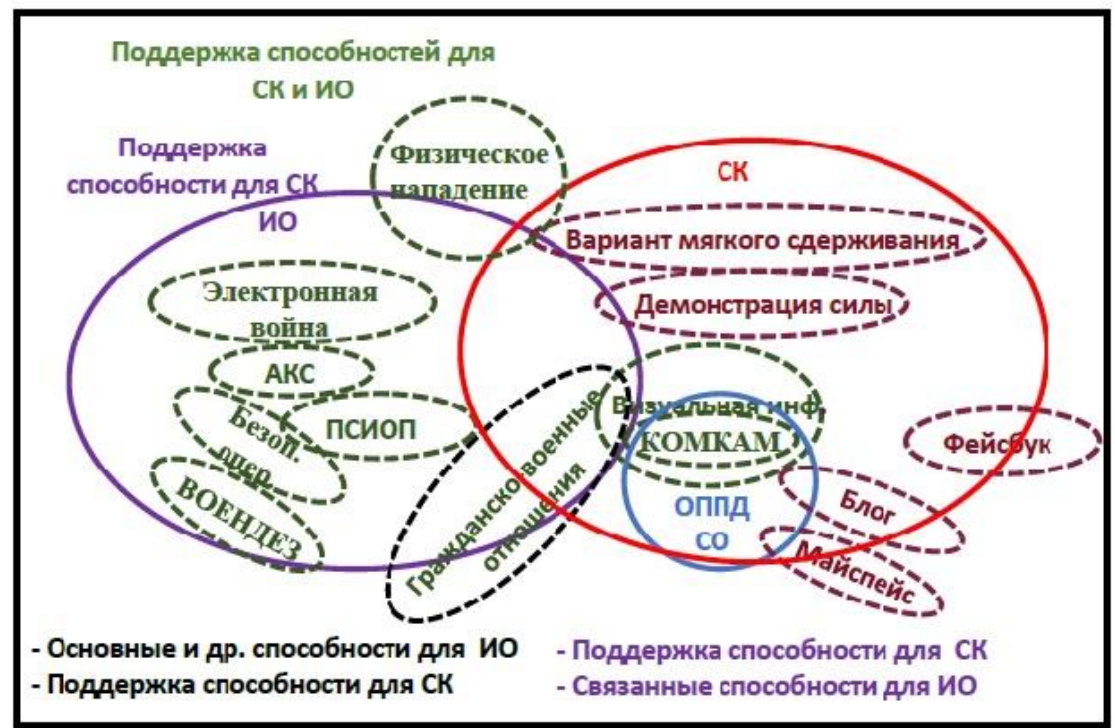

Фигура 1: Взаимоотношения в сфере стратегической коммуникации. ${ }^{9}$

8 Commander's Handbook for Strategic Communication and Communication Strategy, Version 3 (Suffolk, VA: US Joint Forces Command, Joint Warfighting Center, 2010).

9 Commander's Handbook. 
- Понимание разнообразия СМИ и факторов выбора материалов СМИ в качестве коммуникационных каналов

- Формирование посланий в соответствии с дискурсом ведомства

- Адресование посланий целевой аудитории с учетом побочных и/ или «подслушивающих» аудиторий

- Использование фактической информации без лжи, обмана и спекуляций.

Стратегическая коммуникация включает нарративы, которые «предназначены для того, чтобы помочь людям понять события, связанные с использованием военной силы, таким образом, чтобы это понимание вызвало определенные ощущения или мнения». ${ }^{10}$ Нарратив интерпретируется как «рассказ, объясняющий действия актора, для того, чтобы оправдать их в глазах его/ее аудитории. Целью нарратива является руководством для принятия решений, обеспечивающих их согласованность. Он работает как бренд институции». ${ }^{11}$ В результате эмпирического исследования констатируется, что «для того, чтобы быть эффективными, нарративы должны одновременно резонировать с основными ценностями целевой аудитории и представлять убедительное причинно-следственное описание, которое связывает события в единую объяснительную рамку». ${ }^{12}$

Сильные нарративы характеризуются четырьмя основными элементами ${ }^{13}$ :

- Они артикулируют четкую и убедительную цель миссии

- Они содержат обещание военного успеха

- Они должны быть внутренне согласованными и непротиворечивыми

- Они имеют малочисленных и/или слабых конкурентов.

\section{Стратегчческая коммуникация, пропаганда и контрпропаганда}

В наши дни стратегическая коммуникация рассматривается как нечто отличное от пропаганды и контрпропаганды в плане перспективы средств и методов. Стратегическая коммуникация основывается на классическом опре-

10 Andreas Antoniades, Ben O'Loughlin, and Alister Miskimmon, "Great Power Politics and Strategic Narratives," Working Paper No. 7 (2010), The Centre for Global Political Economy, University of Sussex, по состоянию на 3 августа 2016. https://doi.org/ $10.4324 / 9781315770734$.

11 Reding, Weed, and Ghez, "NATO's Strategic Communications, " X.

12 Antoniades, O'Loughlin, and Miskimmon, "Great Power Politics," 5.

13 Jens Ringsmose and Berit K. Børgesen, "Shaping public attitudes towards the deployment of military power: NATO, Afghanistan and the use of strategic narratives," European Security 20, no. 4 (2011): 505-528, по состоянию на 3 августа 2016. doi:10.1080/ 09662839.2011.617368, 513-514. 
делении пропаганды - использование фактической и точной информации, - хотя «слово 'пропаганда' само по себе в течение последнего столетия было слишком перегружено багажом, чтобы быть полезным в сегодняшнем контексте». ${ }^{14}$ Во время Второй мировой войны пропаганда стала могущественным оружием в арсенале нацистов и была превращена в технологию «Большой лжи». В результате, сам термин был скомпрометирован и стал синонимом лжи и обмана.

Имея конечной целью воздействие на целевую аудиторию и стимулирование ее к действиям путем предоставления достоверной информации, отвечающей на вопрос 'Почему?', стратегическая коммуникация не использует, или скорее, не должна использовать инструменты дезинформации и манипуляции, ассоциируемые с пропагандой, так как это может иметь противоположный эффект - потерю доверия. К примеру, Стратегическая коммуникация НАТО направлена на координирование всех информационных и коммуникационных способностей, а это невозможно осуществлять, если эта концепция ассоциируется с обманом: введение в заблуждение позволено только при использовании определенных военных способностей, но не всем и каждому и не в каждой стране. ${ }^{15}$

В охват стратегической коммуникации не входит контрпропаганда, поскольку она использует те же средства, что и пропаганда. К примеру, в Украине контрпропаганда считается неэффективной в плане расхода энергии и финансов, когда идет речь о современных информационных войнах: «Самая большая ошибка, которую мы можем совершить, это тратить все свое время и всю свою энергию на противодействие лжи /... /». ${ }^{16}$ Посол Пьятт считает, что инициатива Украины, направленная на контролирование информационного потока и на «зеркальный ответ» современной пропаганды, не имеет успеха:

Большой ошибкой украинского государства и украинского народа является попытка создать фабрику троллей подобно Санкт-Петербургу, раздувая нашу контрпропаганду в социальных медиа. Большой ошибкой является создание «Министерства правды» [Министерства информации Украины], которое пытается генерировать альтернативные истории, поскольку Украине не нужна пропагандистская машина, ей нужна более объективная информация. ${ }^{17}$

14 Richard Halloran, "Strategic Communication," Parameters 37 (Autumn 2007): 4-14, accessed August 3, 2016, http://strategicstudiesinstitute.army.mil/pubs/parameters/ Articles/07autumn/halloran.pdf, 6.

15 Reding and Weed, "NATO's Strategic Communications", 12.

16 Geoffrey Pyatt, Remarks by Ambassador Pyatt at the "Countering Information War in Ukraine," Conference, January 29, 2016. In: Speeches and Interviews by Ambassador Geoffrey R. Pyatt - Embassy of the USA in Ukraine, по состоянию на 3 августа 2016, http://ukraine.usembassy.gov/speeches/pyatt-01292016.html.

17 Пьятт, Заметки посла Пьятта. 
Стратегическая коммуникация само по себе не является универсальным средством, гарантирующим успех ведомства сектора безопасности и положительного отношения общества. «Положительные и достоверные нарративы создают иммунитет населению против враждебности. Поддержание этой достоверности требует, чтобы дела соответствовали словам ${ }^{18}$

\section{Перспективы для имиджа ведомства сектора безопасности}

\section{Сущность имиджа}

Имидж ведомства сектора безопасности - это представление аудитории об этой организации, которое пустило корни в массовом и/или индивидуальном сознании. ${ }^{19}$ Имидж формируется и развивается в результате пропускания внешней информации об этом ведомстве и его деятельности через сеть текущих стереотипов. Имидж всегда является социально тенденциозным. Имидж связан с репутацией, которая, со свой стороны, основана на предшествующей деятельности ведомства, и являясь социальным восприятием ведомства, имидж основывается на настроениях, стереотипах и информации, получаемых извне. Таким образом, имидж является социальным конструктом, основанном на толкованиях и настроениях аудитории.

Имидж связан со стереотипическими и прототипическими идеями о ведомстве, как и должно быть, и может замещать или представлять данное ведомство в восприятиях публики.

Имидж является ценным средством для повышения авторитета ведомства, что приводит к устойчивости и социальному развитию. Общественная поддержка является критически важной для реформы сектора безопасности и зависит не только от самых реформ, но и от общественного восприятия, основанного на дискурсе ведомства и отражении в масс-медиа этого процесса и деятельности сектора безопасности в целом.

Имидж является для ведомства средством коммуникации, которое оказывает влияние на восприятие аудиторией дискурса ведомства. В то же время имидж, среди прочего, формируется этим дискурсом.

\section{Процесс формирования имиджа}

Имидж какого-либо ведомства сектора безопасности формируется опытом прямого взаимодействия с этим ведомством и опосредствованным опытом, содержащимся в том, что говорят об этом ведомстве другие (отдельные лица, СМИ и другие средства коммуникации).

18 Antti Sillanpää, "Strategic communications and need for societal narratives" (paper presented at The Riga Conference 2015, Riga, November 13, 2015), по состоянию на 3 августа 2016, www.rigaconference.Iv/rc-views/22/strategic-communications-andneed-for-societal-narratives.

19 Андрей В. Олянич, Презентационная теория дискурса (Москва: Гнозис, 2007), 107. 


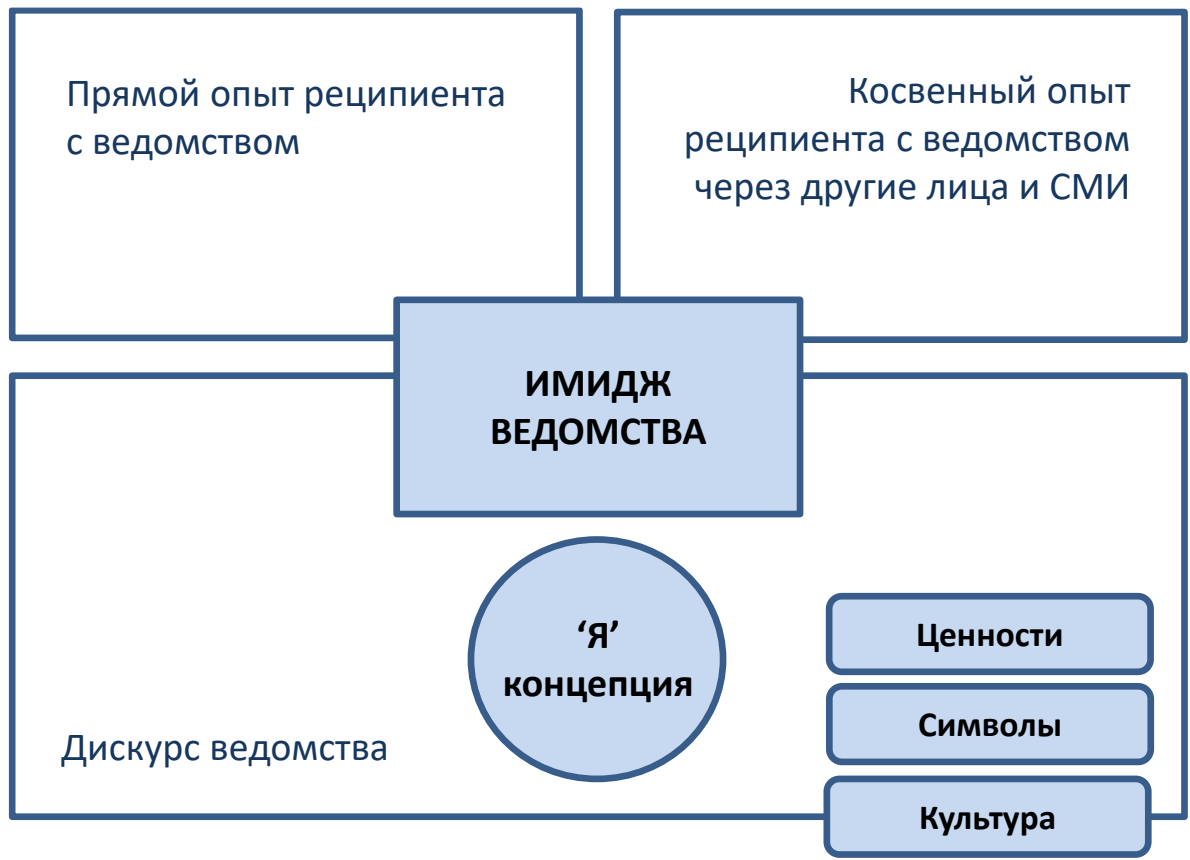

Фигура 2: Коммуникационная сфера формирования имиджа ведомства сектора безопасности.

Учитывая, что неполное знание и/или искривленные послания могут навредить имиджу, ведомство должно заполнить коммуникационное пространство своим дискурсом. Таким образом, существуют три основные области, в которых формируется имидж ведомства сектора безопасности (Фигура 2):

- Прямой опыт взаимодействия реципиента с ведомством

- Опосредствованный опыт реципиента от взаимодействия с ведомством других лиц и масс-медиа

- Дискурс ведомства (вебсайты, медиа, пресс-конференции и т.д.).

Имидж ведомства формируется явным и неявным образом. Каждое сообщение СМИ о вооруженных силах или органов правопорядка содержит формирующий имидж аспект. Поэтому, формирование позитивного образа должно основываться на определенной стратегии в виде плана коммуникационного влияния на реципиента.

Чтобы оказывать влияние на процесс формирования имиджа, ведомство должно моделировать основной элемент имиджа - его Я-концепцию, которая является компромиссом между «настоящим Я» и «идеальным Я». Желаемый имидж для ведомства сектора безопасности должен обеспечивать минимизацию расхождения между Я-концепцией и отношением аудитории к ведомству. Поэтому выбираются подходящие формирующие имидж сим- 
волы и концепции для вербализации желаемого имиджа, а затем эта модель помещается в реальный контекст в форме дискурса ведомства. Это делается коммуникаторами - отделами или лицами, которые отвечают за стратегическую коммуникацию ведомства.

Дискурс ведомства является областью, которой коммуникатор может управлять, где он/она может вербализировать Я-концепцию и куда он может встроить ценности, символы и культуру ведомства. Если с этой сферой правильно обращаться, она может оказывать влияние на две другие области и создает фильтр в сознании целевой аудитории, через который воспринимается внешняя информация о ведомстве. Этот фильтр может бить достаточно сильным, чтобы блокировать любую отрицательную информацию о «проступках» ведомства. На практике, этот фильтр соответствует фреймовой теории семантики Лакоффа, согласно которой «фреймы являются мысленными конструкциями, формирующими способ, с помощью которого мы видим мир». ${ }^{20}$ Согласно ему:

Создание фреймов критически важно, поскольку фрейм, однажды созданный в уме читателя (слушателя, зрителя и т.д.), ведет эту личность почти неизбежно к заключению, желаемому создателем фрейма, и блокирует учет других возможных фактов и толкований. ${ }^{21}$

Основываясь на когнитивном и прагматическом анализе исследуемого материала, автор предлагает таксономию коммуникативных стратегий формирования имиджа, которая построена на следующих признаках (Таблица 1):

- Содержание желаемого имиджа ведомства сектора безопасности

- Объектно-пространственные характеристики имиджа

- Намерения отправителя, которые обуславливают выбор стратегии и тактики

- Лингвистические средства для реализации тактики.

Имиджевые стратегии являются гибкими и могут быть реализованы с помощью ряда коммуникационных приемов. Ссылка на общие ценности включает ценности любого ведомства сектора безопасности (Служба), нации (Лояльность, Патриотизм) и общества (Мастерство, Правда).

20 George Lakoff, The ALL NEW Don't Think of an Elephant! Know Your Values and Frame the Debate (White River Junction, VT: Chelsea Green Publishing, 2014), xv.

21 Lakoff, The ALL NEW Don't Think of an Elephant!, 8. 
Таблица 1: Таксономия стратегий формирования имиджа.

\begin{tabular}{|c|c|c|c|}
\hline Этап & Цель & Сущность & $\begin{array}{l}\text { Возможности } \\
\text { стратегии }\end{array}$ \\
\hline $\begin{array}{l}\text { Формирование } \\
\text { имиджа }\end{array}$ & Утверждение & $\begin{array}{l}\text { Инициирова- } \\
\text { ние имиджа }\end{array}$ & $\begin{array}{l}\text { - Взывать к об- } \\
\text { щим ценностям } \\
\text { - Самовведение }\end{array}$ \\
\hline $\begin{array}{l}\text { Усиление/навязыва- } \\
\text { ние имиджа }\end{array}$ & $\begin{array}{l}\text { Переподтвержде- } \\
\text { ние }\end{array}$ & $\begin{array}{l}\text { Активизация } \\
\text { имиджа }\end{array}$ & $\begin{array}{l}\text { - Взывать к об- } \\
\text { щим ценностям } \\
\text { • Представление } \\
\text { деятельностей }\end{array}$ \\
\hline $\begin{array}{l}\text { Восстановление } \\
\text { имиджа }\end{array}$ & Очищение & $\begin{array}{l}\text { Коррекция } \\
\text { имиджа }\end{array}$ & $\begin{array}{l}\text { - Легитимация } \\
\text { действий } \\
\text { - Смягчение } \\
\text { - Управление } \\
\text { впечатлением }\end{array}$ \\
\hline $\begin{array}{l}\text { Нанесение ущерба } \\
\text { имиджу }\end{array}$ & Ниспровержение & $\begin{array}{l}\text { Подрыв ими- } \\
\text { джа }\end{array}$ & $\begin{array}{l}\text { - Дискредитация } \\
\text { - Дискриминация } \\
\text { • Диффамация }\end{array}$ \\
\hline
\end{tabular}

\section{Стратегии восстановления имиджа}

Последние новости и аналитические публикации в средствах массовой информации (июль 2016: полиция в США стреляет, французская полиция не успела предотвратить теракт в Ницце) показывают, что существует серьезная необходимость в ремонте имиджа этих ведомств с тем, чтобы восстановить доверие общества и расширить сотрудничество. У. Л. Бенуа заявляет, что «запятнанная репутация может нанести ущерб нашей убедительности, поскольку доверие в целом и надежность в частности являются важными для убедительности». ${ }^{22}$ Негативный имидж имеет два основных элемента: ответственность (за правонарушения) и оскорбительность (для общества).

В рамках теории восстановления имиджа считается, что угрозы имиджу неизбежны, по крайней мере, по четырем причинам ${ }^{23}$ :

- Наш мир располагает ограниченными ресурсами

- События не поддаются контролю и иногда они мешают нам выполнять свои обязанности

22 William L. Benoit, "Image Repair Theory in the Context of Strategic Communication," in The Routledge Handbook of Strategic Communication, 304.

23 Benoit, "Image Repair Theory," 303. 
- Иногда мы допускаем оплошности, делаем добросовестные ошибки или позволяем, чтобы наше поведение руководствовалось слишком сильно нашими собственными интересами

- Факт, что мы являемся личностями с разными приоритетами, может приводить к конфликтам, проистекающим из наших конкурентных целей.

Ведомство должно принимать решения по этим угрозам, заниматься или не заниматься ими. Тривиальными обвинениями заниматься не стоит, тогда как «проигнорировать существенное обвинение будет ошибкой». ${ }^{24}$ Нападки на ведомство являются значимыми, если считается, что они могут нанести ущерб репутации ведомства «в глазах группы или аудитории, которые важны для источника». ${ }^{25}$

Так как коммуникация располагает потенциалом для восстановления запятнанного имиджа, восстановление имиджа направлено на улучшение коммуникации и на реформирование отношения аудитории. В этом деле есть два ключевых предположения: коммуникация является деятельностью, направленной на достижение определенной цели, и поддержание положительной репутации является одной из главных целей коммуникации. ${ }^{26}$ Основные коммуникационные стратегии для восстановления имиджа обобщены в Таблице 2. Надо отметить, что дискурс для восстановления имиджа является частью более широкой кризисной коммуникации наряду с другими имиджами в отношение других видов кризисов.

Реципиент послания, направленного на восстановление имиджа, определяется на основе агента, наносящего ущерб имиджу, и целевой аудитории послания, наносящего ущерб имиджу или выпада, которым ведомство озабочено. Ведомству может быть необходимо восстановить свою репутацию в глазах представителя, наносящего вред имиджу, или более широкой целевой аудитории, или в глазах аудитории, пренебрегая агентом, наносящим вред имиджу.

\section{Имидж ведомств сектора безопасности: лучшие практики и са- мые большие провалы}

Сегодня Вооруженные силы и Национальная гвардия Украины стараются создать позитивный имидж с тем, чтобы добиться поддержки общества, используются разные каналы, в том числе и национальные СМИ, официальные вебсайты и социальные медиа. Мониторинг СМИ и социальных медиа показывает, что некоторые из мер, предпринятых в этом направлении, эффективны, другие приводят к недоразумениям и приносят больше вреда,

24 Benoit, "Image Repair Theory," 305.

25 Benoit, "Image Repair Theory," 307.

26 Benoit, "Image Repair Theory," 305. 
Таблица 2: Стратегии восстановления имиджа.

\begin{tabular}{|c|c|c|c|}
\hline Стратегия & $\begin{array}{l}\text { Целевой ком- } \\
\text { понент }\end{array}$ & Цель & $\begin{array}{l}\text { Возможности стра- } \\
\text { тегии }\end{array}$ \\
\hline \multirow[t]{2}{*}{$\begin{array}{l}\text { Отрицание } \\
\text { вины или } \\
\text { оскорбитель- } \\
\text { ности }\end{array}$} & Ответственность & $\begin{array}{l}\text { Отрицание об- } \\
\text { винений, смяг- } \\
\text { чение обвине- } \\
\text { ний }\end{array}$ & $\begin{array}{l}\text { - Отрицание ответ- } \\
\text { ственности } \\
\text { - Перекладывание } \\
\text { вины на других } \\
\text { - Уменьшение от- } \\
\text { ветственности } \\
\text { - Хорошие намере- } \\
\text { ния }\end{array}$ \\
\hline & $\begin{array}{l}\text { Оскорбитель- } \\
\text { ность }\end{array}$ & $\begin{array}{l}\text { Уменьшение } \\
\text { воспринимае- } \\
\text { мой оскорби- } \\
\text { тельности } \\
\text { данного дей- } \\
\text { ствия }\end{array}$ & $\begin{array}{l}\text { - Поддержка } \\
\text { - Минимизация } \\
\text { • Дифференциация } \\
\text { - Превосходство } \\
\text { - Нападение на } \\
\text { обвинителя } \\
\text { - Компенсация }\end{array}$ \\
\hline $\begin{array}{l}\text { Признание } \\
\text { проступка }\end{array}$ & & & $\begin{array}{l}\text { - Просить прощение } \\
\text { - Обещать } \\
\text { разрешить } \\
\text { проблему }\end{array}$ \\
\hline Отрицание & & & $\begin{array}{l}\text { - Простое } \\
\text { отрицание } \\
\text { - Сваливание вины }\end{array}$ \\
\hline
\end{tabular}

чем пользы, в плане общего восприятия этих ведомств. Критически важным является знать, что говорить и как это делать, как пропагандировать корпоративные ценности, как представлять информацию о процессе реформ и т.д. «Действительная политика означает, по крайней мере, столько же, как и то, в каких рамках она преподносится». ${ }^{27}$ Все это относится к области стратегической коммуникации.

Для целей данного исследования были рассмотрены несколько примеров лучших практик и очевидных провалов.

27 Frank Luntz, Words That Work: It's Not What You Say, It's What People Hear (New York: Hyperion, 2007), 3. 


\section{Опрос общественного мнения, наблюдения и фокус-группы}

Для того, чтобы оценить и валидировать стратегию формирования имиджа, направленную на его изменение или улучшение, коммуникаторам ведомства необходима обратная связь. В 2003 году Центр демократического контроля над Вооруженными силами (ДКВС) в Женеве создал широкую картину публичного имиджа безопасности, обороны и вооруженных сил в Европе 28 на основе опросов общественного мнения и обзоров. Данная публикация, конечно, не отражает текущую ситуацию, поскольку многое изменилось за последние 13 лет; она, скорее, подчеркивает необходимость и полезность комплексных опросов общественного мнения. Так как такие опросы (а также фокус-группы и дискуссии) являются дорогостоящими мероприятиями, их можно заменить Интернет обзорами, которые могут дать, как минимум, преставление об имидже ведомства.

\section{"Внедренные» репортеры}

Одним из приемов коммуникации позитивного имиджа вооруженных сил более широкой аудитории является так называемые «встроенные репортеры» - представители СМИ, получающие опыт из первых рук «в реальных условиях» в войсках, чтобы потом поделиться своими впечатлениями с публикой. Ранее в Ираке, а затем в Украине, аудитория получала картину из первых рук жизни войск США и Вооруженных сил Украины. Опыт США показал, что «даже если сюжеты не получают достаточно широкого национального отражения, они имеют хорошее региональное освещение, и во многих случаях, региональное освещение является более подходящим». ${ }^{29}$ Эффективность «внедренных репортеров» зависит от степени доверия к ним и достоверности их посланий.

\section{Поличия в качестве ньюсмейкера}

Имидж ведомств сектора безопасности в США весьма позитивен; общественность относится к вооруженным силам с большим уважением. В то же время, беспорядки в Фергюсоне в 2014 году оживили дебаты об отношении органов правопорядка к афроамериканцам и об использовании силы полицией. СМИ сыграли большую роль в представлении фактов и в формировании настроений аудитории в отношении беспорядков и к полиции в целом.

В последних случаях в США, когда полиция стреляла, полицейские не взяли на себя ответственность за то, что были застрелены два человека, и эти случаи применения оружия разгневали афроамериканское население страны. Понимая как ответственность, так и оскорбительность действий, предъявляемых полиции в обвинениях, начальник управления полиции в

28 Marie Vlachová, ed., Public Image of Security, Defence and the Military in Europe (Belgrade/Geneva: Goragraf and DCAF, 2003).

29 Commander's Handbook, IV-30. 
Батон Руже сделал заявление на пресс-конференции, ${ }^{30}$ являющееся классическим посланием для восстановления имиджа, которое содержало следующие ключевые элементы:

- взятие на себя ответственности, в том числе личный запрос на проведение расследования

- $\quad$ реакция в отношении затронутых полицейских: отстранение от работы, отпуск

- смягчение вины: реакция на звонок на номер 911

- призыв к проведению прозрачного независимого расследования

- обращение к властям: к генеральному прокурору США и ФБР

- приглашение к сотрудничеству для обеспечения справедливого расследования и просьба о проявлении понимания.

Эта пресс-конференция являлась попыткой нарушить ритм негативного развития событий. Но она провалилась, так же как и несколько других, имевших место на странице Facebook полицейского управления. К сожалению, уже сформированный отрицательный имидж не был исправлен. В результате этого полиция в США все еще ассоциировалась с неизбирательным насилием и огнем на поражение по афроамериканцам, что стало благоприятной почвой для применения концептуального противопоставления «МЫ против НИХ» в форме «ПОЛИЦИЯ против АФРОАМЕРИКАНЦЕВ». Этот конфликт получил дополнительный импульс в результате организации движения \#BlackLivesMatter [Жизнь черных имеет значение] в 2013 году и множества демократических протестов. Антагонизм «ПОЛИЦИЯ против АФРОАМЕРИКАНЦЕВ» превратился в расовую проблему, и это привело к действиям, направленным против полиции, при которых в течение десяти дней были убиты восемь полицейских.

Возможно, что ситуация усугубилась и вышла из-под контроля благодаря негативному имиджу полиции в США, который сделал невозможным восприятие дискурса полиции в качестве средства разрешения конфликта.

\section{Правильные формулировки}

Успех формирования имиджа ведомства сектора безопасности, так же как и эффективность стратегической коммуникации ведомства, зависит от выбора основных концепций для дискурса и их конкретной вербализации в контекстах разных аудиторий. К примеру, в 1993 году Лунц советовал Руди Джулиани избегать слова «преступность» и «преступники». Он придерживался мнения, что «публика ставит 'личную и общественную безопасность' выше, чем 'борьбу с преступностью' (являющейся весьма проце-

30 Baton Rouge Police Press Conference on Alton Sterling 7/6/16, по состоянию на 3 августа 2016, https://www.youtube.com/watch?v=II0CTp_x5Tg. 
дурной проблемой) или даже выше, чем 'жесткую политику в отношении преступников' (имеющую карательный оттенок), тогда как 'безопасность', хотя и являющаяся несколько абстрактным понятием, определенно имела личный оттенок, и прежде всего имела характер аспирации - высшая ценность и желаемый результат борьбы с преступностью. ${ }^{31}$ Успех Джулиани в Нью-Йорке оказал влияние на американский образ мыслей в этом плане, смещая ударение от «преступности» к «безопасному гражданскому обществу».

\section{Ребрэндинг}

Ребрэндинг является инструментом маркетинга и к нему прибегают, имея серьезные причины. Ребрэндинг в секторе безопасности производится, когда имидж ведомства невозможно исправить или когда восстановление требуется делать постоянно. К примеру, Украина, как и некоторые другие страны в этом регионе, получили в наследство от СССР так называемые «внутренние войска». Наличие таких формирований внутри страны поднимало много вопросов, как например «Против кого они будут воевать внутри страны? Против народа?». Репутация и имидж этих военных формирований были полностью запятнаны после столкновений между протестующими на Майдане и этими правоохранительными ведомствами зимой 2013-2014. Последовавшая кампания по ребрэндингу была направлена на достижение примирения между Национальной гвардией и широкой публикой с использованием мотто «Новая и усовершенствованная». Однако, с учетом ограниченного времени и ограниченного финансирования, Национальная гвардия Украины не имела комплексную стратегию ребрэндинга, основанную на миссии, программе и ценностях. В результате этого, процесс воссоздания Национальной гвардии Украины оказался долгим, неструктурированным и хаотическим с внутренними культурологическими конфликтами и одновременного существенного ремонта имиджа.

\section{Совместные усилия}

Для того, чтобы быть успешным, процесс формирования имиджа должен быть скоординированным и интенсивным. Это утверждение можно проиллюстрировать имидж-кампанией, сопровождающей создание бригады быстрого реагирования Национальной гвардии Украины в 2015-2016. В этой кампании по формированию имиджа использовались все наличные инструменты стратегической коммуникации:

- многочисленные послания с положительным уклоном в СМИ, наряду с хвастливыми сообщениями на официальном сайте ведомства и в СМИ

31 Luntz, Words That Work, 178. 
- информативные речи Командующего Национальной гвардии Украины

- тематические пресс-конференции и интервью с руководителями разных уровней

- положительные оценки Президента

- положительная оценка иностранных военных властей, например, генерала Ходжиса.

В результате этой имидж-кампании, бригада быстрого реагирования сейчас имеет в обществе положительный имидж, пользуется специальным вниманием и является символом эффективных реформ в секторе безопасности Украины.

\section{Указания по формированию имиджа ведомств сектора безопас- ности}

Для достижения цели этого исследования можно следовать двум главным направлениям в плане составления указаний для формирования имиджа ведомств сектора безопасности: эффективный дискурс для формирования имиджа и разработка политики.

\section{Эффективный дискурс, формирующий имидж}

Эта часть указаний относится, скорее, к тактике и составлена для тех коммуникаторов, которые осуществляют стратегическую коммуникацию.

\section{Фактор реципиента}

С практической точки зрения, фактор реципиента является наиболее важным для стратегической коммуникации, поскольку «не важно, что ты говоришь; важно, что слышат люди». ${ }^{32}$ Соответственно, формирование имиджа зависит также от реципиента. Более того, реципиенту принадлежат все имиджи, формированные в его/ее сознании. Таким образом, все послания стратегической коммуникации должны быть скомпонованы с учетом переменных целевой аудитории: возраст, гендер, занятие, жизненный опыт, образование и убеждения. В наше время даже ораторские умения касаются не только речи, они связаны со знанием социальных условий и улавливанием того, что ожидает аудитория. ${ }^{33}$ Идеальное послание должно доносить до реципиента персональный смысл и персональные ценности. К примеру, женщины в целом лучше воспринимают истории, анекдоты и метафоры, тогда как мужчины в большей степени ориентированы на факты и стати-

32 Luntz, Words That Work.

33 Ronald R. Krebs, Narrative and the Making of US National Security (New York: Cambridge University Press, 2015), 32. 
стику. ${ }^{34}$ С учетом того, что молодые люди читают меньше, послания, связанные с имиджем, должны быть краткими и иметь захватывающие начало и конец.

\section{Ценности}

Ценности являются основой создания имиджа ведомства сектора безопасности. Ценности ведомства должны не противоречить ценностям нации или общества. Любое расхождение в системах ценностей может привести к потенциальному конфликту. Выбор концепции ценностей зависит от миссии и видения ведомства. Обычно ценности ведомства скрупулезно формулируются в виде набора понятий. К примеру, семью основными ценностями Сухопутных сил США являются Верность, Долг, Уважение, Самоотверженная служба, Честь, Честность и Личная отвага. ${ }^{35}$ Ценностями Национальной гвардии Украины являются Честь, Отвага и Закон. ${ }^{36}$

\section{Имидж лидера}

В определенной степени, дискурс для формирования имиджа определяется личностью руководителя. Дело не только в том, что руководитель формулирует концепцию развития ведомства, но и в том, что лидер персонифицирует ведомство. Аудитория имеет склонность формировать свое отношение на основе качеств лидера, таким образом обязательным требованием к руководителю является наличие сильной коммуникационной индивидуальности. В то же время, «носители посланий, которые сами по себе являются самым лучшим посланием, всегда верны себе». ${ }^{37}$ Имеются примеры, когда лидеры являются преувеличено публичными личностями, предпочитают интенсивно общаться с аудиторией через социальные медиа. Найти необходимый баланс для лидера является искусством, но открытость обычно способствует положительному образу ведомства. Это предполагает, что руководитель будет принимать участие в пресс-конференциях, интервью, публичных событиях и т. д.

\section{Послание}

Для хорошего послания специальное значение имеют содержание, структура и функция. Как и при всякой стратегической коммуникации, послание, создающее имидж, должно быть убедительным по своему характеру. Результаты более ранних обзоров показывают, что убеждение и информирование являются двумя главными функциями послания стратегической коммуникации из числа шести обозначенных Хазелтоном: облегчать, информировать, убеждать, принуждать, способствовать достижению договоренности и решать проблемы. Стратегии убеждения приводили к самому высо-

\footnotetext{
34 Luntz, Words That Work, 43.

35 "The Army Values," по состоянию на 3 августа 2016, https://www.army.mil/values.

36 "National Guard of Ukraine," по состоянию на 3 августа 2016, http://ngu.gov.ua/ua.

37 Luntz, Words That Work, 92.
} 
кому уровню участия широкой публики. ${ }^{38} \mathrm{~K}$ примеру, «убедительное оформление использования военной силы может, таким образом, в некоторой степени иммунизировать или защитить общественное мнение от конвенциональных последствий увеличения числа человеческих потерь». ${ }^{39}$

Чтобы послание было убедительным, специальное внимание следует уделять его структуре. Оформление послания таким образом, чтобы оно создавало контекст и было адекватным, зависит от ряда таких факторов, как реципиент, канал, время и тема послания. Уже доказано, что эффективным является «дать контекст 'почему' до 'так, что' и 'как', поскольку порядок, в котором представляется информация, определяет контекст, и он может быть так же важен, как сама сущность информации». ${ }^{40} \mathrm{~K}$ примеру, сообщения с информации о «проступках» ведомства должны иметь структуру сэндвича: положительный факт, касающийся ведомства или среды безопасности в целом, - негативная информация, являющаяся ядром данного сообщения, - другой положительный факт, связанный с ведомством или шагами, которые следует предпринять. Эти выводы соответствуют основному языковому правилу, которое противоречит логике: «A+B+C не обязательно равно $\mathrm{C}+\mathrm{B}+\mathrm{A} »{ }^{41}$

Убедительность посланий достигается не только рациональными аргументами и фактами. Для многих аудиторий эмоциональный компонент может быть доминирующим. Персонализация и гуманизация послания способствует включению эмоционального запоминания. ${ }^{42}$

Отталкиваясь от правила, что «если вы хотите добиться внимания людей, сначала начните говорить на их языке», ${ }^{43}$ "Десять правил эффективного языка» ${ }^{44}$ применимы для посланий, формирующих имидж: Простота, Краткость, Достоверность, Непротиворечивость, Новизна, Крепость, Стремление, Визуализация, Вопросы и Контекст.

Содержание формирующего имидж послания передается языком и визуальными средствами. Визуальные средства постепенно приобретают все большее значение благодаря калейдоскопической картине мира молодого поколения, являющейся результатом сдвига нашего мышления в сторону презентации информации в виде «клипов». Визуальные средства используются широко для поддержки дискурсов ведомств сектора безопасности. Краткий девиз «Целься высоко» на официальном сайте набора военнослу-

38 Kelly P. Werder, "A Theoretical Framework for Strategic Messaging," in The Routledge Handbook of Strategic Communication, 278.

39 Ringsmose and Børgesen, "Shaping public attitudes," 506.

40 Luntz, Words That Work, 26.

41 Luntz, Words That Work, 41.

42 Luntz, Words That Work, 18.

43 Luntz, Words That Work, 3.

44 Luntz, Words That Work, 12-28. 
жащих для Военно-воздушных сил США ${ }^{45}$ поддерживается волнующим видео, ориентированным на эмоциональную сферу реципиента.

Формирующие имидж сообщения могут быть вложены в девизы и лозунги. Качественное измерение послания имеет большее значение, чем количественное. Основным требованием является создавать успешные, эффективные послания, которые застревают в нашем мозгу и никогда не исчезают, а именно они и заставляют людей действовать. ${ }^{46}$

\section{Непротиворечивость и когерентность создающего имидж дискурса}

Непротиворечивость и когерентность связаны как с фактором реципиента, так и с фактором разнообразия аудитории. Когерентность не является линейной характеристикой. Для разных аудиторий нужны разные послания. Вместо распределения одного и того же «универсального» послания по разным каналам, послания, формирующие имидж, как и дискурс ведомства в целом, представляют собой широкий спектр различных посланий по одной теме для разных контекстов и для разных аудиторий. Суть в том, что эти послания должны быть непротиворечивыми, скоординированными, когерентными и взаимно усиливающими друг друга.

\section{Восстановление}

Стратегическая коммуникация сейчас считается интегральной функцией, а не приложением к планированию и проведению всех военных операций и всей военной деятельности. Она является процессом командования и управления, направленным на обеспечение оперативного успеха и сплоченности альянса. ${ }^{47}$ Исследование «Картографирование СтратКом практик в странах НАТО» показывает, что:

СтратКом все еще далеко от состояния поддерживаемой, а не поддерживающей способности, так как коммуникаторы не находятся в самом сердце стратегии, есть строгое требование для управления «сверху вниз» на военном и политическом уровнях. ${ }^{48}$

Потенциал имиджа повышать способности организации или ведомства все еще не признается явным образом в существующей политике стратегической коммуникации. К примеру, имидж не включен в Политику НАТО по стратегическим коммуникациям, но среди ее шести ключевых принципов упоминается «оказание влияния на общественные взгляды», что напрямую связано с имиджем.

\footnotetext{
45 "U.S. Air Force Recruiting," по состоянию на 3 августа 2016, www.airforce.com. 46 Luntz, Words That Work, 126.

47 Rita LePage, Mapping of StratCom practices in NATO countries (Riga, Latvia: NATO Strategic Communications Centre of Excellence, 2015), по состоянию на 3 августа 2016, http://www.stratcomcoe.org/mapping-stratcom-practices-nato-countries-0.

48 LePage, "Mapping of StratCom practices."
} 
Отталкиваясь от роли имиджа для стратегической коммуникации ведомства сектора безопасности и необходимости осуществления инициатив «сверху вниз» в отношении Национальной гвардии Украины можно было бы иметь в виду следующие пункты:

- Необходимо разработать политику или доктрину стратегической коммуникации. Эта инициатива могла бы привести к созданию отдельной доктрины или плану, который перечислит ключевые элементы желаемого имиджа, которые нужно передать разным аудиториям:

- Видение, миссию и ценности ведомства, разработанные на основе мандата ведомства;

- Роль, структура, права и ответственности коммуникатора;

- Требование проводить ССВУ анализ (сильные стороны, слабые, возможности, угрозы) имиджа ведомства на регулярной основе, чтобы осуществлять мониторинг ситуации и утверждать согласованность имиджа с «И» концепцией;

- Подготовка планов на случай чрезвычайных ситуаций для предупреждения потенциальных угроз имиджу и «подготовки ответов без стресса и спешки». ${ }^{49}$ Основываясь на этих планах, генерировать стандартные послания в качестве ответов на ожидаемые угрозы. «В случае кризисов, эти планы следует адаптировать к конкретной ситуации и вдумчиво осуществлять, не следуя слепо написанному. Кроме того, планы реакции на случай кризиса следует периодически пересматривать или актуализировать в случае необходимости». 50

\section{Заключение}

Стратегическая коммуникация является термином, обобщающим широкий спектр коммуникаций ведомств сектора безопасности, в том числе дискурс и действия. В секторе безопасности стратегическая коммуникация относится ко всем существующим информационным и коммуникационным способностям и не ограничивается деятельностью СМИ. Поскольку стратегическая коммуникация направлена на "завоевание умов и сердец", ${ }^{51}$ имидж ведомства сектора безопасности становится ключевым инструментом в

49 Benoit, "Image Repair Theory," 309.

50 Benoit, "Image Repair Theory," 309.

51 David Kilcullen, "If we lose hearts and minds, we will lose the war," The Spectator, May 20, 2009, по состоянию на 3 августа 2016, https://www.spectator.co.uk/2009/05/ifwe-lose-hearts-and-minds-we-will-lose-the-war/. 
этом деле, поскольку он оказывает влияние на настроения реципиентов в отношение ведомства, их поведение и действия поддержки.

Имидж ведомства сектора безопасности является социальным конструктом, основанном на восприятии аудитории, ее интерпретации и настроениях. Сформированный в рамках стратегической коммуникации, он функционирует как фильтр в сознании реципиента при получении внешней информации о ведомстве.

Для ведомства сектора безопасности создание имиджа является комплексным процессом, поддерживаемым соответствующей политикой или доктриной, которая декларирует «И» концепцию ведомства с обозначенными ценностями. Коммуникатор, отвечающий за процесс формирования имиджа, разрабатывает дискурс ведомства в соответствии с политикой, осуществляет мониторинг реализации имиджа в реальном контексте и производит его модификацию для усиления или восстановления имиджа, когда это необходимо.

В качестве инструмента стратегической коммуникации, формирование имиджа основывается на тех же принципах объективности, открытости, достоверности и доверия, избегания обмана и манипуляций. Однако, всегда существует вероятность, что имидж ведомства сектора безопасности может быть неправильно использован ведомством или СМИ. Дальнейшие исследования этой проблемы могли бы способствовать идентификации механизма двустороннего влияния формирования имиджа и стратегической коммуникации в секторе безопасности и его возможностей и угроз.

\section{6 авторе}

Доктор Ирина Лисичкина является доцентом, заведующим кафедрой филологии, перевода и языковой коммуникации в Национальной академии Национальной гвардии Украины, Харьков, Украина. 